\title{
Evaluation of selected reasons and analysis of the course of delivery accompanied by a partner
}

\section{Ocena wybranych przyczyn i analiza przebiegu porodu z udziatem partnera}

\author{
Beata Bąk ${ }^{1}$, Marek Sikorski², Aleksandra Woźniak² \\ 1Department of Perinatology and Gynaecological-Obstetrical Nursing, Institute of Nursing and Obstetrics, Faculty of Health Science, \\ Jan Kochanowski University, Kielce, Poland \\ Head of Department: Prof. Marek Sikorski MD, PhD \\ 2Delivery Room, Świętokrzyskie Centre for Mothers and Newborns, Specialised Hospital, Kielce, Poland \\ Head of Department: Andrzej Witczak PhD
}

Key words: delivery, partner, support.

Słowa kluczowe: poród, partner, wsparcie.

\begin{abstract}
Introduction: The popularity of family deliveries has been increasing for several years, so it is reasonable to make an evaluation of the factors that influence decisions on choosing this type of delivery as well as an evaluation of the effects of such a decision.

Aim of the research: The aim of the research was to define how the age of a woman in labour, her marital status, residence, her and her partner's education, financial situation, parity, and participation in classes at a childbirth school can affect a decision on having a family delivery. The research also defined the objective indices of the birth-giving process: the method of its completion, the performance of episiotomy, application of painkillers, and the condition of the newborn. The quality of the completed labour was evaluated in the subjective opinions of young mothers.

Material and methods: By means of a survey and analysis of medical documentation, 80 women giving birth in the company of their partners were compared with 80 women giving birth in the traditional way.

Results: Place of residence, economic status, parity, education, and attendance of a childbirth school are strongly associated with the chosen form of childbirth. Episiotomy was performed more frequently in women who gave birth in the presence of their partners. Newborn babies received similar scores in the Apgar Scale. Painkillers were applied more often in family deliveries than in conventional ones.

Conclusions: The main advantages of a family delivery include the feeling of higher self-esteem and safety, and the strengthening of ties between partners. The disadvantages included fear of worsened quality of sexual life.
\end{abstract}

\section{Streszczenie}

Wprowadzenie: Po kilku latach wzrostu popularności porodów rodzinnych zasadna jest ocena czynników wpływających na decyzję o odbyciu tego typu porodu, jak również jej skutków.

Cel pracy: Określenie, w jaki sposób takie czynniki, jak wiek rodzącej, stan cywilny, miejsce zamieszkania, wykształcenie jej i partnera, status materialny, dotychczasowa rodność i udział w zajęciach szkoły rodzenia, wpływają na podjęcie decyzji o porodzie rodzinnym. Analizowano także obiektywne wskaźniki przebiegu porodu, w tym: sposób jego zakończenia, wykonanie zabiegu nacięcia krocza, zastosowanie środków przeciwbólowych, stan noworodka. Badano jakość przebytego porodu w subiektywnej ocenie młodych matek.

Materiał i metody: Za pomocą ankiety i analizy dokumentacji medycznej porównano 80 kobiet rodzących z udziałem partnera i 80 rodzących tradycyjnie. Zebrane dane poddano analizie statystycznej.

Wyniki: Wiek i stan cywilny nie był istotny z punktu widzenia decyzji o rodzaju porodu. W towarzystwie partnerów częściej niż bez nich rodziły mieszkanki miast, dla których był to pierwszy poród, oraz pary z wyższym wykształceniem, wysokim statusem ekonomicznym i te, które uczęszczały do szkoły rodzenia. Porody przebiegały drogami i siłami natury niezależnie od ich formy i były źródłem pozytywnych doświadczeń, mimo że kobiety rodzące z partnerem nieznacznie częściej odczuwały brak intymności. Nacięcie krocza częściej wykonywano u kobiet, które rodziły z partnerem. Noworodki uzyskały podobną liczbę punktów w skali Apgar. W czasie porodów rodzinnych częściej niż w czasie konwencjonalnych stosowano środki przeciwbólowe.

Wnioski: Do głównych zalet porodu rodzinnego zalicza się poczucie dowartościowania, bezpieczeństwa i pogłębienie więzi partnerskich, natomiast do wad obawę o pogorszenie jakości życia seksualnego. 


\section{Introduction}

A partnership between a man and a woman, which includes co-operating and complementing each other, enables fulfilment of aims in life and a common, intimate existence with each other. The awareness of mutual reliance in any situation creates a feeling of psychic comfort and safety [1]. The birth of a child is the climax of the process of procreation. The medicalisation of labour in the first half of the twentieth century led to a considerable fall in infant mortality, but at the same time labour became an activity deprived of privacy and intimacy. Women, regardless of their expectations, were forced to give birth without the presence of their immediate family. The father could welcome the child only after it left the hospital. In 1953 in France the husband of a woman in labour was allowed for the first time to enter the delivery room. In Poland men first appeared in the labour ward 30 years later [2]. Since then different aspects of family delivery have been considered by obstetricians, psychologists, and midwives [3]. In recent years in Poland, as well as internationally, the number of deliveries accompanied by a close person has been systematically increasing $[4,5]$. Pregnant women who want to give birth in the company of their partners justify their decision mainly by their fear of the alien hospital environment, labour pains, the feeling of threat, and a lack of self-confidence, while partners wish to give the woman a feeling of safety, and reduce her loneliness and stress by their presence [6, 7]. A man who accompanies his partner in labour supports her psychically, helps her to find the most comfortable position, and by touching and kissing her helps her to relax the muscles of the birth canal, which facilitates physiological delivery [8]. The majority of couples express satisfaction with their decision on common participation in the delivery of their child and express a positive influence of this event on their future life. The partner's participation in the delivery objectively improves the clinical course of labour in the form of reduced loss of blood, less damage to soft tissues of the birth canal, less pain, and faster delivery [9]. However, some couples fear a common delivery, mentioning above all the fear of losing sexual attractiveness, a feeling of shame, aesthetic reasons, and the unbearable sight of a suffering partner. In their opinion, these experiences may have a negative impact on their relationship in the future [10]. After a few years of increasing popularity of family deliveries, it is reasonable to make an evaluation of factors that influence decisions on choosing this type of delivery, as well as an evaluation of the effects of such a decision.

\section{Aim of the research}

The aim of the research was to define how the factors such as the age of a woman in labour, her marital status, place of residence, education, financial situation, parity, and participation in classes at a childbirth school can affect the decision about a family delivery. The research defined the objective indices of the birth-giving process, including the method of its completion, the performance of episiotomy, application of painkillers, and the scores in the Apgar Scale received by the newborn baby in the first minute of life. The quality of the completed labour was evaluated in the subjective opinions of young mothers, as well as its influence on relations between the partners and any disadvantages of a family delivery in the women's opinion.

\section{Material and methods}

The research material was based on the survey and analysis of the medical documentation of 80 women who gave birth with their partner's participation. The gathered data were compared with the data concerning the same number of women who gave birth in a conventional way in the general delivery room. The criteria of inclusion in the research were: single pregnancy with no complications, lack of contraindications in the obstetrical and gynaecological reports, and delivery in accordance with the schedule. The surveyed groups were selected at random, by means of a constant rule of selecting every second family delivery and every second conventional delivery. Women in the early puerperal stage were surveyed in the Świętokrzyskie Centre for Mothers and Newborns in Kielce after having been informed of the aims of the research and the method of giving answers, and after having given their consent. Participation in the research was voluntary and anonymous. In defining the method of completion of the childbirth, caesarean section was taken into consideration, which, in emergency indications, is defined as a section performed after delivery has started (after the latent phase) and performed soon after such indications have appeared [11].

\section{Statistical analysis}

The results were analysed in view of statistical accordance of measurable qualities by means of $\chi^{2}$ test. For statistical conclusions, a significance level of $p<$ 0.05 was adopted.

\section{Results}

The ages of the women giving birth in the company of their partners ranged between 18 and 40 years, which gave an average of 27 years and 3 months. In the group of women giving birth in a conventional way the age range was $18-38$ years, which gave an average of 27 years. Among family deliveries, primiparas statistically prevailed over multiparas (73.8\% and $26.2 \%$, respectively). In the group of conventional childbirths, the statistics were reversed (prim- 
iparas 37.5\% and multiparas 62.5\%). The percentage of women giving birth with partners to whom they were married was $90 \%$. Only $10 \%$ of them were single. Similar results with regard to marital status were received among women giving birth without partners ( $85 \%$ and $15 \%$, respectively). Women giving birth with partners came from the city in $65 \%$ of cases, and $35 \%$ of them were from villages. Among the women who gave birth in the general delivery room, villagers dominated over city-dwellers (55\% and 45\%, respectively), with the statistical significance referring to the place of residence. The level of education in the two compared groups was statistically significant, both with reference to women and to the men who accompanied them. Women giving birth with partners had the following level of education: higher $(63.8 \%$,), secondary (13.7\%), elementary (12.5\%), and vocational (10\%). Women giving birth without partners present were as follows: higher (43.8\%), secondary (30\%), vocational (15\%), and elementary (11.2\%). Fathers who were present at the birth had completed higher education in $60 \%$ of cases, secondary education in $15 \%$ of cases, vocational education in $15 \%$ of cases, and elementary education in $10 \%$ of cases. The structure of education of fathers who awaited the birth of their child outside the delivery room was shaped slightly differently: most (37.7\%) men had vocational education, followed by secondary (30\%), then higher (25\%), and finally elementary (7.5\%). Half of the women giving birth with partners (50\%) evaluated their material status as high, $43.7 \%$ as middle, and only $6.3 \%$ as low. The women who gave birth without partners declared differently: slightly more than half (52.5\%) evaluated their material conditions as middle, $32.5 \%$ as high, and $15 \%$ as low. The difference in the financial status between women who had family birth and those who went through conventional labour were statistically significant. In the group of family deliveries, half of the couples attended a childbirth school. Among the women who gave birth in the general delivery room, only $15 \%$ of couples attended a childbirth school. These proportions were statistically significant. The women giving birth in both compared groups are characterised in Table 1.

The partner deliveries in three-quarters of the cases went without complications that would decide

Table 1. Description of women in labour in the group of women giving birth with participation of a partner and in the group of women giving birth without participation of a partner

\begin{tabular}{|c|c|c|c|c|c|c|}
\hline \multirow[t]{2}{*}{ Description of women in labour } & & \multicolumn{2}{|c|}{$\begin{array}{l}\text { Women giving birth } \\
\text { with a partner } \\
(N=80)\end{array}$} & \multicolumn{2}{|c|}{$\begin{array}{l}\text { Women giving birth } \\
\text { conventionally } \\
(N=80)\end{array}$} & \multirow{2}{*}{$\begin{array}{c}\begin{array}{c}\text { Statistic } \\
\text { essentiality }\end{array} \\
p\end{array}$} \\
\hline & & $n$ & $\%$ & $n$ & $\%$ & \\
\hline Marital status & $\begin{array}{l}\text { Single } \\
\text { Married }\end{array}$ & $\begin{array}{c}8 \\
72\end{array}$ & $\begin{array}{l}10.0 \\
90.0\end{array}$ & $\begin{array}{l}12 \\
68\end{array}$ & $\begin{array}{l}15.0 \\
85.0\end{array}$ & $>0.05$ \\
\hline Residence & $\begin{array}{l}\text { Country } \\
\text { City }\end{array}$ & $\begin{array}{l}28 \\
52\end{array}$ & $\begin{array}{l}35.0 \\
65.0\end{array}$ & $\begin{array}{l}44 \\
36\end{array}$ & $\begin{array}{l}55.0 \\
45.0\end{array}$ & $<0.05$ \\
\hline Education of women in labour & $\begin{array}{l}\text { Elementary } \\
\text { Vocational } \\
\text { Secondary } \\
\text { Higher }\end{array}$ & $\begin{array}{c}10 \\
8 \\
11 \\
51\end{array}$ & $\begin{array}{l}12.5 \\
10.0 \\
13.8 \\
63.8\end{array}$ & $\begin{array}{c}9 \\
12 \\
24 \\
35\end{array}$ & $\begin{array}{l}11.3 \\
15.0 \\
30.0 \\
43.8\end{array}$ & $<0.05$ \\
\hline $\begin{array}{l}\text { Education of partners of women } \\
\text { in labour }\end{array}$ & $\begin{array}{l}\text { Elementary } \\
\text { Vocational } \\
\text { Secondary } \\
\text { Higher }\end{array}$ & $\begin{array}{c}8 \\
12 \\
12 \\
48\end{array}$ & $\begin{array}{l}10.0 \\
15.0 \\
15.0 \\
60.0\end{array}$ & $\begin{array}{c}6 \\
30 \\
24 \\
20\end{array}$ & $\begin{array}{l}7.5 \\
37.5 \\
30.0 \\
25.0\end{array}$ & $<0.05$ \\
\hline Material status & $\begin{array}{l}\text { High } \\
\text { Middle } \\
\text { Low }\end{array}$ & $\begin{array}{c}40 \\
35 \\
5\end{array}$ & $\begin{array}{c}50.0 \\
43.7 \\
6.3\end{array}$ & $\begin{array}{l}26 \\
42 \\
12\end{array}$ & $\begin{array}{l}32.5 \\
52.5 \\
15.0\end{array}$ & $<0.05$ \\
\hline Parity & $\begin{array}{l}\text { Primiparas } \\
\text { Multiparas }\end{array}$ & $\begin{array}{l}59 \\
21\end{array}$ & $\begin{array}{l}73.8 \\
26.2\end{array}$ & $\begin{array}{l}30 \\
50\end{array}$ & $\begin{array}{l}37.5 \\
62.5\end{array}$ & $<0.05$ \\
\hline $\begin{array}{l}\text { Couple's participation in classes } \\
\text { in a childbirth school }\end{array}$ & $\begin{array}{l}\text { Yes } \\
\text { No }\end{array}$ & $\begin{array}{l}40 \\
40\end{array}$ & $\begin{array}{l}50.0 \\
50.0\end{array}$ & $\begin{array}{l}12 \\
68\end{array}$ & $\begin{array}{l}15.0 \\
85.0\end{array}$ & $<0.05$ \\
\hline $\begin{array}{l}\text { Average age of women in labour } \\
\text { [years] }\end{array}$ & & & & & & $>0.05$ \\
\hline
\end{tabular}


Table 2. Performance of episiotomy in the group of women giving birth by means of natural birth canal and natural forces with participation of a partner and in the group of women giving birth without participation of a partner

\begin{tabular}{|lccccc|}
\hline $\begin{array}{l}\text { Episiotomy (women giving birth by } \\
\text { means of natural birth canal and } \\
\text { natural forces) }\end{array}$ & $\begin{array}{c}\text { Women giving birth } \\
\text { with a partner } \\
(N=60)\end{array}$ & $\begin{array}{c}\text { Women giving birth } \\
\text { conventionally } \\
(N=56)\end{array}$ & $\begin{array}{c}\text { Statistic } \\
\text { essentiality }\end{array}$ \\
\cline { 2 - 5 } & $n$ & $\%$ & $n$ & $\%$ & $p$ \\
Yes & 40 & 66.7 & 26 & 46.5 & $<0.05$ \\
No & 20 & 33.3 & 30 & 53.5 & \\
\hline
\end{tabular}

Table 3. Course of a delivery in objective indices in the group of women giving birth with participation of a partner and in the group of women giving birth without participation of a partner

\begin{tabular}{|c|c|c|c|c|c|c|}
\hline \multirow{2}{*}{\multicolumn{2}{|c|}{ Objective indices of delivery course }} & \multicolumn{2}{|c|}{$\begin{array}{l}\text { Women giving birth } \\
\text { with a partner } \\
\qquad(N=80)\end{array}$} & \multicolumn{2}{|c|}{$\begin{array}{l}\text { Women giving birth } \\
\text { conventionally } \\
(N=80)\end{array}$} & \multirow{2}{*}{$\begin{array}{c}\begin{array}{c}\text { Statistic } \\
\text { essentiality }\end{array} \\
p\end{array}$} \\
\hline & & $n$ & $\%$ & $n$ & $\%$ & \\
\hline $\begin{array}{l}\text { Method of completion } \\
\text { of delivery }\end{array}$ & $\begin{array}{l}\text { Delivery by means } \\
\text { of natural birth canal } \\
\text { and natural forces: } \\
\text { caesarean section }\end{array}$ & 60 & 75.0 & 56 & 70.0 & $>0.05$ \\
\hline Application of painkillers & $\begin{array}{l}\text { Yes } \\
\text { No }\end{array}$ & $\begin{array}{l}59 \\
21\end{array}$ & $\begin{array}{l}73.7 \\
26.3\end{array}$ & $\begin{array}{l}51 \\
29\end{array}$ & $\begin{array}{l}63.8 \\
36.2\end{array}$ & $>0.05$ \\
\hline $\begin{array}{l}\text { Newborn baby's average } \\
\text { score in the Apgar Scale }\end{array}$ & & \multicolumn{2}{|c|}{9.36} & \multicolumn{2}{|c|}{9.08} & $>0.05$ \\
\hline
\end{tabular}

Table 4. Course of a delivery in a subjective evaluation in the group of women giving birth with participation of a partner and in the group of women giving birth without participation of a partner

\begin{tabular}{|c|c|c|c|c|c|c|}
\hline \multicolumn{2}{|c|}{ Objective indices of delivery course } & \multicolumn{2}{|c|}{$\begin{array}{l}\text { Women giving birth } \\
\text { with a partner } \\
(N=80)\end{array}$} & \multicolumn{2}{|c|}{$\begin{array}{l}\text { Women giving birth } \\
\text { conventionally } \\
(N=80)\end{array}$} & \multirow{2}{*}{$\begin{array}{c}\begin{array}{c}\text { Statistic } \\
\text { essentiality }\end{array} \\
p\end{array}$} \\
\hline & & $n$ & $\%$ & $n$ & $\%$ & \\
\hline $\begin{array}{l}\text { Childbirth as a source of } \\
\text { experience }\end{array}$ & $\begin{array}{l}\text { Positive } \\
\text { Negative }\end{array}$ & $\begin{array}{l}40 \\
40\end{array}$ & $\begin{array}{l}50.0 \\
50.0\end{array}$ & $\begin{array}{l}44 \\
36\end{array}$ & $\begin{array}{l}55.0 \\
45.0\end{array}$ & $>0.05$ \\
\hline $\begin{array}{l}\text { Feeling of infringement of } \\
\text { intimacy }\end{array}$ & $\begin{array}{l}\text { Yes } \\
\text { No }\end{array}$ & $\begin{array}{l}14 \\
66\end{array}$ & $\begin{array}{l}17.5 \\
82.5\end{array}$ & $\begin{array}{c}6 \\
74\end{array}$ & $\begin{array}{c}7.5 \\
92.5\end{array}$ & $>0.05$ \\
\hline $\begin{array}{l}\text { Feeling of greater self- } \\
\text { esteem }\end{array}$ & $\begin{array}{l}\text { Yes } \\
\text { No }\end{array}$ & $\begin{array}{l}48 \\
32\end{array}$ & $\begin{array}{l}60.0 \\
40.0\end{array}$ & $\begin{array}{l}33 \\
47\end{array}$ & $\begin{array}{l}43.2 \\
58.8\end{array}$ & $<0.05$ \\
\hline Sense of safety & $\begin{array}{l}\text { Yes } \\
\text { No }\end{array}$ & $\begin{array}{c}72 \\
8\end{array}$ & $\begin{array}{l}90.0 \\
10.0\end{array}$ & $\begin{array}{l}30 \\
50\end{array}$ & $\begin{array}{l}37.5 \\
62.5\end{array}$ & $<0.05$ \\
\hline $\begin{array}{l}\text { Strengthening of ties } \\
\text { between partners }\end{array}$ & $\begin{array}{l}\text { Yes } \\
\text { No }\end{array}$ & $\begin{array}{c}72 \\
8\end{array}$ & $\begin{array}{l}90.0 \\
10.0\end{array}$ & $\begin{array}{l}24 \\
56\end{array}$ & $\begin{array}{l}30.0 \\
70.0\end{array}$ & $<0.05$ \\
\hline
\end{tabular}

on their completion by a caesarean section. The percentage of women giving birth through the natural birth canal and by the forces of nature, and who had undergone an episiotomy, was $66.7 \%$. Childbirths in the group of women giving birth in a conventional way went in a similar way; however, episiotomy was performed in only $46.5 \%$ of women. The majority of episiotomies in the family delivery group was statis- tically significant (Table 2). Women accompanied by partners more frequently needed administration of painkillers in comparison with the women giving birth without partners $(73.7 \%$ and $63.8 \%$, respectively), although the obtained results were not statistically significant. The average number of scores in the Apgar Scale in the first minute of life (maximum value 10) was very similar in both compared groups (with 
Table 5. Answers to question: "Does labour in the presence of a partner have any disadvantages?"

\begin{tabular}{|lccccc|}
\hline \begin{tabular}{l} 
Does labour in the presence $\begin{array}{l}\text { Wo partner have any } \\
\text { disadvantages }\end{array}$ \\
\cline { 2 - 5 }
\end{tabular} & $\begin{array}{c}\text { Women giving birth } \\
\text { with a partner } \\
(N=80)\end{array}$ & $\begin{array}{c}\text { Women giving birth } \\
\text { conventional } \\
(N=80)\end{array}$ & $\begin{array}{c}\text { Statistic } \\
\text { essentiality }\end{array}$ \\
No & $n$ & 66.2 & 8 & $\%$ & $p$ \\
Yes & 53 & 33.8 & 72 & 90.0 & $<0.05$ \\
\hline
\end{tabular}

Table 6. Disadvantages of a family delivery, in the opinion of women giving birth with participation of a partner and women giving birth without participation of a partner. Explanation: This analysis relates only to respondents who had stated that family labour has disadvantages. From the multiple choice of answers, the respondents chose one answer, the most important in their opinion

\begin{tabular}{|lccccc|}
\hline Disadvantages of family delivery & $\begin{array}{c}\text { Women giving birth } \\
\text { with a partner } \\
(N=27)\end{array}$ & $\begin{array}{c}\text { Women giving birth } \\
\text { conventionally } \\
(N=72)\end{array}$ & $\begin{array}{c}\text { Statistic } \\
\text { essentiality }\end{array}$ \\
\cline { 2 - 6 } & $n$ & & $n$ & $\%$ & $p$ \\
Worsened quality of sexual life & 12 & 44.5 & 8 & 11.1 & $<0.05$ \\
Feeling of embarrassment & 5 & 18.5 & 35 & 48.6 & 23.6 \\
Lack of intimacy & 5 & 18.5 & 17 & 16.7 & \\
Other & 5 & 18.5 & 12 & \\
\hline
\end{tabular}

partner 9.36, without partner 9.08). Table 3 presents the delivery course data in objective indices.

For the half of women giving birth with partners (50\%), the childbirth was a source of positive feelings. Slightly more, i.e. 55\%, of women giving birth in the general delivery room were of the same opinion, but without statistical significance. According to the predominant majority of women preferring a family delivery (82.5\%), labour did not infringe upon their sense of intimacy. Of the same opinion, there were more $(92.5 \%)$ women giving birth in the general delivery room, but which was statistically insignificant. For $60 \%$ of women giving birth with partners, labour boosted their self-esteem, $90 \%$ felt it gave them a sense of security. Also, 90\% claimed that it made the ties between them and their partners stronger. In the group of women giving birth without partners, labour gave only $43.2 \%$ of them a deeper sense of self-esteem, $37 \%$ felt a sense of safety, and only $30 \%$ claimed that the delivery strengthened the ties between them and their partners. These results were statistically significant. The course of the delivery in the subjective opinions of the women in labour is presented in Table 4 .

More than $66 \%$ of women who gave birth in the presence of their partners claimed (Tables 5 and 6) that this method of labour had no disadvantages. $44.5 \%$ of those who disagreed with this statement were concerned about the quality of their sex life as a consequence, and $18.5 \%$ mentioned the following: embarrassment, lack of intimacy, and 'other'. Women who gave birth without being unaccompanied by their partner, who claimed that a family birth had disadvantages (90\%), mentioned embarrassment in the first instance (48.6\%), followed by a lack of intimacy (23.6\%), and 'other' (16.7\%). Only 11.1\% were concerned about their sex life. The above results were statistically significant.

\section{Discussion}

Men and women make the decision to have a family delivery together. Exceptions to this include situations where already during pregnancy there were indications for its completion by means of a caesarean section. The results showed that the majority of the surveyed couples who decided on a family delivery were joined in matrimony and lived in a city. Guzikowski and Maciejewski et al. presented similar observations $[6,12]$. While the place of residence (city/ country) could have an influence on the choice of the type of delivery, marital status could not be a decisive factor because in both compared groups the percentage of single and married women was similar. Also, the age of women did not prove to be significant in choosing the type of childbirth, in contrast to the research results presented by other authors, who state that the younger the parents are, the more often they 
decide on a family delivery [13]. The obtained results prove that for nearly three-quarters of couples their decision on a family delivery concerned the first pregnancy, which other authors confirm [14, 15]. In the group of women giving birth in a conventional way multiparas prevailed. We may assume that some of these women had already given birth with their partners and perhaps for some indefinable reasons did not want to repeat that experience. This thesis warrants further studies to assess the long-term effects of a family delivery. The discussed research results show that the education of women giving birth as well as the education of fathers present at the delivery had an influence on choosing the type of childbirth. While among mothers in both compared groups higher education prevailed, this percentage was higher still in the group of women giving birth with partners. In the group of fathers present at the delivery, higher education was dominant whereas in the group of fathers who did not accompany the women, vocational and secondary education prevailed. Similarly, according to Redshaw and Henderson, couples having higher education participated in a family delivery more often than other couples, and the majority of pregnancies had been planned [16].

A delivery accompanied by a partner was chosen more frequently by couples assessing their material status as high whereas among women giving birth in a traditional way, couples of medium material status prevailed, which points to the importance of material affluence in taking decisions on the type of childbirth. Couples of a high social and economic status, living in cities, have a greater opportunity to attend a childbirth school. The results showed that half of the couples choosing a family delivery attended a childbirth school, while among women giving birth traditionally there were only $15 \%$ of such couples. Therefore, this type of activity, during which parents learn inter alia how to make conscious decisions together, how to experience a delivery, do exercises together and handle pain, contribute significantly to deciding on a family delivery [17]. However, other authors' research results show that the couples choosing a family delivery rarely participated in any professional preparation for childbirth [18, 19]. According to Sioma-Markowska and Poręba, only $23.6 \%$ of couples that later decided on a family delivery attended a childbirth school [14].

Almost three-quarters of women who gave birth with a partner claimed that the presence of a close person during the delivery gave them a feeling of safety whereas only slightly more than a third of women giving birth traditionally were of the same opinion were. A feeling of safety relaxes the muscles of the birth canal and facilitates effective breathing. Similar results are given by an appropriate body position and exercises with equipment for women in labour, which can be used with the partner's help. Such a procedure quickens labour and protects the perineum against injuries [16]. Symptoms of incoming perineal rupture constitute an indication for prophylactic incision [20]. It could be expected that there would be more prophylactic perineal incisions in the group of women giving birth conventionally than in those giving birth with the family. However, our results showed noticeably higher numbers of perineal incisions in the group of women after a family labour than in the group of women after a conventional labour. This could be due to the fact that in the family-birth group there were more women who gave birth for the first time. First time mothers are prone to perineum injuries; therefore, prophylactic perineal incisions are applied to them more often. Muscle relaxation and effective breathing improve the placental flow and reduce the risk of foetal asphyxia, which is the most frequent indication for an emergency caesarean section [21]. The results, though statistically insignificant, show a smaller number of emergency caesarean sections in the group of family deliveries. Normal childbirth is also indicated by the condition of a newborn baby. In the group of family deliveries, as well as in the group of traditional childbirths, newborn babies in the first minute of life obtained an average score of 9.36 and 9.08, respectively, in the Apgar Scale, which is evidence of good health condition immediately after birth, regardless of the selected type of delivery. Similarly, Rudnicka et al., in her comparison of newborn babies in conventional and family deliveries, reported 9 as the average Apgar result in both groups [22].

Due to the influence of psychic comfort on the clinical course of delivery, one could have expected a lower application of painkillers in the group of family deliveries. Such observations were reported by Kaźmierczak et al. [13]. However, as our results showed, women giving birth with partners used these drugs more often than did women giving birth traditionally.

Labour became a source of greater self-esteem for a much higher proportion of women giving birth with partners, in comparison to women giving birth in a conventional way, and in $90 \%$ of cases family births also strengthened ties between the partners. Similar conclusions on this issue are drawn by Steen et al. and Nilsson et al. [23, 24], but the surveyed women were in the early puerperium stage, so an explicit evaluation of the impact of the childbirth-related experiences on the quality of a relationship seems premature.

For all of the surveyed women, labour was a source of positive experience. The women giving birth with a partner rarely had a feeling of infringement of their intimacy, similarly to the women surveyed by Wdowiak et al. [25]. Curiously, the women that shared the same sensations prevailed in the group of women giving birth conventionally. One should assume that the question in the survey was inaccurate and did not make it possible to state explicitly that in the case of 
family deliveries intimacy had been infringed by the partner's presence. Infringement of intimacy could have resulted from the presence of other, undesirable people. Such a thesis is supported by the evaluation of the disadvantages of a family childbirth, in which a definite, statistically significant proportion of the women giving birth with a partner declared only to a few per cent that childbirth accompanied by a close person infringed their intimacy, while the same answer was given by every fifth surveyed woman giving birth conventionally.

Analysis of the literature on the subject shows that some of the couples who choose a family delivery complain about worsened quality of their sexual life. In the case of men, post-delivery impotence occurs, which manifests itself by an erection disorder while women are convinced of their own lack of physical attractiveness [8, 26, 27]. The research results of our study prove that the fear of a worsened quality of sexual life is the most frequently mentioned disadvantage of a family delivery, according to women who gave birth in the company of their partners.

The decision to have a family delivery is highly individual and should be taken together. The couple has the right to change it even at the last moment. At the same time, a family delivery is not an optimal solution for everybody. Emotional blackmail, following fashion, or curiosity that obliges the man to accompany the woman in this experience that is so important to the couple, may have a negative influence on the permanence of the relationship.

\section{Conclusions}

Place of residence, education, wealth, historical childbirth, and preparation for the delivery are factors that determine the decision about the nature of the childbirth. Delivery accompanied by a partner is more often chosen by women from cities, with higher education and high economic status, who are firsttime mothers, and who have attended a childbirth school. The course of a delivery, characterised by objective indices, such as the way of its completion, performance of episiotomy, application of painkillers, and Agar Scale score that the a newborn baby receives in the first minute of life, are not different in the group of family deliveries than in the group of conventional deliveries. Therefore, there is no connection between the course of the childbirth characterised by the objective indicators and its nature. There is a relationship between a partner's participation in the childbirth and the positive subjective assessment of its course. A delivery accompanied by a partner, in women's subjective opinions, is a source of higher self-esteem, gives a feeling of security, and affects the strengthening of emotional ties between the couple. Fear of worsened quality of sexual life is the greatest disadvantage of a family delivery.

\section{References}

1. Lew-Starowicz Z. Seksualność człowieka w ujęciu wieloaspektowym [Polish]. Wydawnictwo Vizja Press \& It, Warszawa 2009

2. Chołuj I. Urodzić razem i naturalnie [Polish]. Źródła Życia. Mszczonów 2008.

3. Goodman P, Mackey MC, Tavakoli AS. Factors related to childbirth satisfaction. J Adv Nurs 2004; 46: 212-9.

4. O'Brien M, Shemilt I. Working fathers: earning and caring. Working paper no. 18. Equal Opportunities Commission: Manchester 2003.

5. Laudański T, Lipecka-Kidawska E. Analiza porodów rodzinnych w świetle 20 lat doświadczeń [Polish]. Klin Perinat Gin 2004; 1: 17-8.

6. Guzikowski W. Porody rodzinne we współczesnym położnictwie [Polish]. Wydawnictwo Akademii Medycznej, Wrocław 2002.

7. Premberq A, Carlsson G, Hellstrom AL, et al. First-time father's experiences of childbirth - a phenomenological research. Midwifery 2011; 27: 848-53.

8. Więś M, Dmoch-Gajzlerska E. Znaczenie seksualne partnera w porodzie fizjologicznym [Polish]. Położna Nauka i Praktyka 2011; 3: 54-6.

9. Gajewska M. Przekształcenie wyobrażeń na temat miłości rodzicielskiej w dzisiejszym dyskursie medycznym. In: Kocha się raz? Miłość w relacjach partnerskich i rodzinnych [Polish]. Muszyński M (ed.). Wydawnictwo Adam Marszałek, Toruń 2009; 229-30.

10. Szczawińska M. Razem czy osobno? Poród rodzinny [Polish]. Wydawnictwo AZ, Kraków 2000.

11. Murphy DJ, Liebling R, Verity L, et al. Early maternal and neonatal morbidity associated with operative delivery in second stage of labour: a cohort research. Lancet 2001; 358: 1203-7.

12. Maciejewski J, Krawczyńska M, Jaczyński R. Poród rodzinny w doświadczeniu Kliniki Położnictwa i Ginekologii Instytutu Matki i Dziecka w Warszawie [Polish]. Klin Perin Gin 2004; 1: 62-3.

13. Kaźmierczak W, Fiegler P, Węgrzyn P, et al. Rola porodu rodzinnego we współczesnym położnictwie [Polish]. Wiad Lek 2006; 59: 317-20.

14. Sioma-Markowska U, Poręba R. Analiza postaw ojców $\mathrm{w}$ porodzie rodzinnym w materiale Katedry i Oddziału Klinicznego Ginekologii i Położnictwa w Tychach Śląskiej Akademii Medycznej [Polish]. Perin Neonat Gin 2008; 1 : 141-8.

15. Hildingsson I, Cederlof L, Widen S. Fathers' birth experience in relation to midwifery care. Women Birth 2011; 24: 129-36.

16. Redshaw M, Henderson J. Fathers' engagement in pregnancy and childbirth: evidence from a national survey. BMC Pregnancy Childbirth. 2013; 13: 70.

17. http://www.rodzicpoludzku.pl/Szkola-rodzenia/Program.html

18. Ziółkowska K, Banaszak A, Kamiński P. Wspólne uczestnictwo małżonków w porodzie - korzyści czy ryzyko? [Polish]. Perin Neonat Gin 2004; 1: 90-3.

19. Guzikowski W, Kowalczyk D, Mączka M. Analiza aktualnych form przygotowania do porodu rodzinnego i „tradycyjnego" [Polish]. Klin Perin Gin 2004; 1: 67-70.

20. Nkwabong E, Konam L. Episiotomies during deliveries of singletons in cephalic presentation: the incidence can be reduced. J Obstet Gynecol India 2012; 62: 641-3. 
21. De M, Biswas S, Ganguly RP, et al. Impact of increased rate of caesarean section on perinatal outcome: sociolegal evaluation. J Indian Med Assoc 2011; 109: 312-4.

22. Rudnicka B, Wrońska B, Szymańska I, et al. Ocena wybranych parametrów klinicznych rodzących kobiet i noworodków w przebiegu porodu konwencjonalnego i porodu rodzinnego [Polish]. Perin Neonat Gin 2012; 5: 131-6.

23. Steen M, Downe S, Bamford N, et al. Not-patient and not-visitor: a metasynthesis father's encounters with pregnancy, birth and maternity care. Midwifery 2012; 28 : $362-71$.

24. Nilsson L, Thorsell T, Hartfelt Wahn E, et al. Factors influencing positive birth experiences of first-time mothers. Nurs Res Pract 2013; 2013: 349124.

25. Wdowiak A, Lewicka G, Bąk M, et al. Oczekiwania małżonków odnośnie porodu rodzinnego [Polish]. Med Ogól 2010; 16: 323-30.

26. Edmondson OJ, Psychogiou L, Vlachos H, et al. Depression in fathers in the postnatal period: assessment of the Edinburgh Postnatal Depression Scale as a screening measure. J Affect Disord 2010; 125: 365-8.

27. Lew-Starowicz Z. Kardioseksuologia [Polish]. Wydawnictwo Medical Education, Warszawa 2009.

\section{Address for correspondence:}

\section{Beata Bąk MD}

Department of Perinatology and

Gynaecological-Obstetrical Nursing

Faculty of Health Science

Jan Kochanowski University

al. IX Wieków Kielc 19, 25-317 Kielce, Poland

Phone: +48 692113477

E-mail: beatab5@onet.eu 